\title{
An Error Analysis Of The Cohesive Devices Made By The Students In Writing Paragraph (A Study Of English Department Students Of Letters Faculty)
}

\author{
Rusdiah $^{1}$,Malombassang ${ }^{2}$ \\ 1,2 Sastra Inggris, Fakultas Sastra, Universitas Muslim Indonesia
}

\begin{abstract}
This research investigates cohesive devices errors in paragraphs written by the seventh semester students at UMI Makassar. This graduating paper intends to be a descriptive qualitative research which consist of a detail linguistic description and explanation of cohesive devices errors. It explains how cohesion is used erroneously in the students' writing. The objectives of this research are to know whether there are any cohesive errors in English essays written by the seventh semester students at UMI Makassar, to find out the types of cohesive devices error committed in those paragraphs, and to describe the dominant of errors in using cohesive devices in those paragraphs. The results show that a total of 25 errors are identified in those paragraphs include errors on the use of reference, conjunction and lexical cohesion. Errors on the use of substitution and ellipsis are not found. The percentage of errors on the use of reference is $64 \%$, conjunction $24 \%$, and lexical cohesion $12 \%$. From percentage of each types of errors on the use of cohesive devices, reference becomes the first dominant error, conjunction as the second dominant error, and lexical cohesion as the last dominant error.
\end{abstract}

Keywords: Analysis, lexical, Paragraph

\begin{abstract}
Abstrak
Penelitian ini menyelidiki kesalahan perangkat kohesif dalam paragraf yang ditulis oleh mahasiswa semester tujuh di UMI Makassar. Makalah ini merupakan kualitatif deskriptif yang terdiri dari deskripsi linguistik detail dan penjelasan tentang kesalahan perangkat kohesif. Penelitian ini menjelaskan bagaimana kohesi digunakan secara keliru dalam tulisan siswa. Tujuan dari penelitian ini adalah untuk mengetahui apakah ada kesalahan kohesif dalam esai bahasa Inggris yang ditulis oleh mahasiswa semester tujuh di UMI Makassar, jenis kesalahan perangkat kohesif yang dilakukan dalam paragraf tersebut, dan menggambarkan kesalahan dominan dalam menggunakan perangkat kohesif dalam paragraf tersebut. Hasil penelitian menunjukkan bahwa total 25 kesalahan diidentifikasi dalam paragraf termasuk kesalahan pada penggunaan referensi, konjungsi dan kohesi leksikal. Kesalahan penggunaan subtitusi dan elipsis tidak ditemukan. Persentase kesalahan dalam penggunaan referensi adalah 64\%, konjungsi 24\%, dan kohesi leksikal 12\%. Dari persentase masing-masing jenis kesalahan pada penggunaan perangkat kohesif, referensi menjadi kesalahan dominan pertama, konjungsi sebagai kesalahan dominan kedua, dan kohesi leksikal sebagai kesalahan dominan terakhir.
\end{abstract}

Keywords: analisis, leksikal, kohesi, paragraph

\section{Introduction}

Writing is one of language competences which must be mastered by students. It poses the most challenging task for English learners as foreign language. Ability in this skill will assist them in producing both academic writing and non academic writing such as essays, papers, proposals, and articles as assignment from lecturers.

A Paragraph is a group of related sentences about a single topic. The topic of a para- graph is one, and only one, idea. The first word in paragraph is moved to the right about one - half inch. This is called indenting the first word. Also, there is blank space down both the left and the right sides of the page. These blank spaces are called margins (Hogue, Ann 1996: 3).

The cohesive device is to link one idea or sentence to the others. When writing a paragraph, it will be used cohesive device as the connectors in order to make a logical 
expressions or thoughts. The contributive uses and functions of the cohesive device are really required in writing paragraph. One view of a good paragraph is when it has a correct uses of the cohesive device in linking the sentences in the case of constructing the sentences.

The cohesive device is to link one idea or sentence to the others. When writing a paragraph, it will be used cohesive device as the connectors in order to make a logical expressions or thoughts. The contributive uses and functions of the cohesive device are really required in writing paragraph. One view of a good paragraph is when it has a correct uses of the cohesive device in linking the sentences in the case of constructing the sentences.

In this research, it will use the error analysis to find out the constructions or uses of the cohesive device in writing paragraph. Hence, the study will be also identified the errors made by the students. Besides, the research can improve the students' ability in paragraph writing by using cohesive device as the connectors of the sentences.

Based on those explanations, the writer intends to conduct a research entitled "The Error Analysis of the cohesive device made by the students in writing paragraph. The research will conduct the research of seventh semester students of letters faculty at Indonesia Moslem of University as the object of the research.

Writing is a basic skill of the language in which people can express their ideas or opinions at the paragraph. Even paragraph writing or the organization of a paragraph is the important one in a composition or essay. Writing as one of the language skills is to give descriptions from the smaller ones to the larger units. The common ones is from words to make sentences and sentences will construct the paragraph. Sentence as the parts of the organization paragraph are composed more than one. it must takes topic sentence, supporting sentence, and concluding sentences. The supporting and concluding may be composed of more than one. But, the topic sentence is only one main idea (simple sentence). The explanations of the paragraph can be cleared by some viewers as follows:
Sattayatham \& Ratanapinyowong 2008: 21 provided more details about the essential parts for paragraph writing which include a topic sentence, supporting sentence, details, logical order, logical connectors, a concluding sentence, unity and coherence. The ideas in the paragraph must be presented in logical order by using transition words or connecting words which indicate the relationship between the ideas (chronological,causal, etc).

Error Analysis is the identification, description and explanation of errors that occur both in spoken and written form. Brown (1980:166) says that error analysis is the study of the learnerse error which can be observed, analyzed, and classified to reveal something of the system operating within the learner. Error analysis is used to show students $^{\text {ee }}$ problems. Moreover, it gives information to teacher about the process of acquiring a foreign language made by students. Corder in Richard (1974:25) adds that learner's errors are significant in three different ways. Firstly, errors can tell the teacher about the progress of the learner and how far the learner can apply the teachers ${ }^{\text {ce }}$ method. Secondly, they tell the researcher how actually language is learned; therefore researchers through errors discover strategies applied in acquiring a language. The last, errors can serve as good feedback to learners for self-adjustment, hence they will not make the same errors again. From the definition above, it can be concluded that errors occur when the learners speak or write. An occurring of those areas are caused by the learner still developing acquisition of the L2 (target language) rules system. By classifying errors that learners made, researchers could learn a great deal about the second language acquisition process by inferring the strategies that the learners were adopting. Furthermore, the result of error analysis will inform teacher some problems faced by students.

Error and Mistake

The terms of errors and mistakes actually have identical meaning in teachinglearning process, but they are actually different. For this reason, researcher needs to distinguish both of them. To know the distinction between error and mistake, the writer cited the definition of them. 
According to Brown's statement (1980:165),"an error is a noticeable deviation from the adult grammar of a native speaker, reflecting the inter language competence of the learner". In short, error refers to competence factors caused by systematic failure and consistently. Meanwhile, a mistake as stated by Brown (1980: 165) refers to a performance error that is either a random guess or a "slip" in that it is a failure to use a know system correctly.

Sources of Errors

Brown (1980:166) classifies sources of error into: interlingual errors of interference from the native language, intralingual errors within the target language, context of learning and communication strategies. To limit the discussion, the researcher only discusses errors caused by interlingual and intralingual.

Interlingual Errors

This kind of error is a result of interference from the native language and generally caused by interference of learner's mother tongue language. As stated by Brown (1980), most of the learners ${ }^{\text {ee }}$ errors in the second language result primarily from the learnerse assumption that the second language forms similar to the native language. Interlingual errors occur because there are differences between the first and second languages; however learners still apply their knowledge of first language in learning second language. This is referred to negative transfer, or interference, which can be source of errors in second language. Negative transfer of interference is considered the most frequent cause of second language learners"e errors. For example, English learners say "sheep" for "ship".

Intralingual Errors

Intralingual errors are the negative transfer of items within the target language. In the other words, intralingual errors are the incorrect generalization of rules within the target language. Brown (1980: 162) says "It has been found that the early stages of language learning are characterized by a predominance of interlingual transfer, but once the learner has begun to acquire parts of the new system, more and more transfer generalization within the target language is manifested". Intralingual errors result from faulty or partial learning of the target lan- guage rather than language transfer. They may be caused by the influence of one target language item upon another. For example, learners attempt to use two tense markers at the same time in one sentence since they have not mastered the language yet. When they say: "He is comes here", it is because the singularity of the third person requires "is" in present continuous, and "-s" at the end of a verb in simple present tense. In short, intralingual errors occur as a result of learners ${ }^{\text {ee }}$ attempt to build up concepts and hypotheses about the target language from their limited experience with it. Richards (1974) classifies the intralingual errors into four categories includes: Over generalization, ignorance of rule restrictions, incomplete application of the rules and false concept hypothesized or semantic errors.

\section{Over Generalization}

In the opinion of Jakobovist (as cited in Richards, 1974:174), "over-generalization is the application of previous available strategies in new situations". Over-generalization happens when a learner creates a deviant structure on the basis of his experience of other structure in the target language. It also may occur, for instances, with items which are contrasted in the grammar of the language but do not carry significant and obvious contrast for the learner (Richard, 1974:174).

For example "He can walks". In that example, learners over-generalizes that in the simple present tense, " $\mathrm{s}$ " ending is required by third person singular. The learners fail to realize that "s" ending is not required anymore when a sentence in the simple present tense is introduced by an auxiliary verb. Ignorance of Rule Restrictions

In this type of error, the learner fails to observe the restrictions of existing structures. Some rule restriction errors may be accounted for in terms of analogy and may result from the role learning of rules.

For example: "Falih is the most tall among his friends".

The example above is type of generalization and transfer, since the learner is making use of a previously acquired rule on a new situation.

Paragraph is an important part in the text. When writing, we use the sentences to 
be organized. However, text in wiring is constructed of the paragraph. Paragraph is composed of topic sentence, supporting sentence, and concluding sentence. In this case, people can pour their ideas or feelings by gathering the sentences one another. In sentence combination, it will be needed the connectors that are termed cohesive devices as the topic in this research. The cohesive devices are used in paragraph as one of the requirements in writing paragraph to which we connect one sentence to the others.

Cohesive device is one of the grammatical relations that are used in paragraph writing. It is related to the cohesion which deals with the relations of meaning that exist within the text, and that define it as a text (Halliday, et al,. 1976: 4). The sentence combination that must take the form and meaning are concerned. To make clear of the meaning in cohesive device, it can be viewed from the definition given as follows:

According to Gerot and Wignell, (1994:170), stated that:

"Cohesion is the resources within language that provide continuity in a text, over and above that provided by clause structures and clause complexes". Cohesion helps readers or listeners to understand some missing pieces which are not present in the text but necessary to its interpretation.

Coherence of the text is accomplished in many ways (e.g., using templates from scripts and rhetorical genre forms, via clause selection, and with syntactic markers of various types). Cohesive devices are also used to tie pieces of text together in specific ways. While Levinson's applies to deictic markers of reference, Halliday and Hassan's (1976) system distinguishes five major types of grammatical cohesive ties: Reference, Substitution, Ellipsis, Conjunction, and Lexical ties (Hatch, Evelyn., 1992: 223).

Reference

Reference is one of the parts of the cohesive device which express the specific nature of the information that is signaled for retrieval. In the case of reference the information to be retrieved is the referential, the identity of the particular thing or class of things hat is being referred to; and the cohesion lies in the continuity of reference, whereby the same thing enters into the discourse a second time (Halliday and Hasan., 1976: 31).

To establish reference, we may use lexical items. For example, "Mary" can be used to refer to a person named mary. Once we establish the referent, we can also refer to Mary as "she", at least for the period of time during which our focus is on Mary. The pronoun "she," by itself, has no referent. It is a cohesive tie to the noun "Mary". In addition to lexical items, English uses pronouns, demonstratives, and comparatives for grammatical reference (Hatch, Evelyn., 1992: 223).

Demonstratives

Demonstrative are also cohesive ties and either cataphoric or anaphoric. In the following constructed example, the demonstrative "this" refers to "Magic Motor's special sale is February 14": "If you are buying a car, you should know about this." If the author continues by telling us something related to the sale, the tie is cataphoric, and we expect that "this" will refer not to the noun "sale" but to some larger unit, such as details about special prices or factor rebates. In the example, "this is why esprit is a leader in sports fashion," we assume that the refernt has already been established for "this" the tie, therefore, is anaphoric.

Comparatives

A comparative can also provide a tie to a referent. Most comparatives are used for anaphoric reference. For example, "I'd like more." It is less common for a comparative to be used for cataphoric reference (i.e., to tie the comparative to a noun in the following clause or sentence), but here is an example: "I demand the best. Your service leaves much to be desired.

Substitution

A second major type of cohesive device tie is that of substitution. In constract to reference, substitution refers not to a specific entity but to a class of items. Substitution can have sub-parts. Those are Nominal, Verbal, and Clausal.

Ellipsis

Ellipsis refers to "the omission of an item" (Halliday and Hasan: 1976: 88) that is already understood from the antecedent context. The relation between substitution and ellipsis is very close because it is merely 
that ellipsis is "substitution" by zero (0). What is essential in ellipsis is that some elements are omitted from the surface text, but they are still understood. Thus, omission of these elements can be recovered by referring to an element in the preceding text. Halliday and Hasan (1976:146) assert that there are three types of ellipsis; nominal, verbal, and clausal.

Conjunction

Gerot and Wignell (1994:180) argue that conjunction is the semantic system whereby speakers relate clauses in terms of temporal sequence, comparison and addition. Unlike reference, substitution, and ellipsis, the use of conjunction does not instruct the reader to supply missing information either by looking for it elsewhere in the text or by filling structural slots. Instead, conjunction signals the way the writer wants the reader to relate what is about to be said to what has been said before. Halliday and Hassan describe it as follows: "In describing conjunction as a cohesive device, we are focusing attention not on the semantic relation as such, as realized throughout the grammar of the language, but on one particular aspect of them, namely the function they have of relating to each other linguistic elements that occur in succession but are not related by other, structural means". (Halliday and Hassan, 1978: 227). Halliday and Hasan (1976:243) state that conjunction can be divided into additive, adversative, causal, temporal and other conjunctive items (continuatives).

Lexical Cohesion

Lexical cohesion refers to relationships between and among words in a text ( Gerot and Wignell, 1994:177). It involves the repetition of a noun phrase, or the use of another noun phrase which bears a relation to the antecedent noun phrase. Halliday and Hasan (1976:288) divide lexical cohesion into two main categories: reiteration and collocation.

\section{a. Reiteration}

Reiteration is subdivided into the repetition of a lexical item, the use of a general word to refer back to a lexical item, and the use of a synonym, or super ordinate terms. They will be discussed as follows:

1) Repetition
Restate the same lexical item in a later part of the discourse.

For Example:

There's a flower in the vase. The flower was bought from a market. The word flower is repeated in the second sentence.

2) General Nouns

General nouns are used to refer back to a lexical item such as: person, people, man, woman for human nouns; things, object for inanimate, concrete countable nouns; stuff for inanimate, concrete uncountable; place for location ... etc.

For Example:

The computer should be replaced. That old thing works erratically. The word thing is the general word referring to computer.

3) Synonymy

Synonymy used to express a similar meaning of an item.

For example:

His job is enjoyable. He has never been bored with his work. The words job and work are synonymous.

4) Super Ordinations

It involves the use of general class words.

For Example:

"They went to the Emporium. The shopping mall was large and had a lot of goods. The noun phrase shopping mall is the superordinated term referring to the Emporium".

b. Collocation

Collocation deals with the association of lexical items that regularly co-occur (Halliday and Hasan, 1976:284). Some examples are: "sheep" and "wool", "congress" and "politician" or "college" and "university". Halliday and Hasan (1976:284) assert that such patterns occur freely both within the same sentence boundaries since they are independent of the grammatical structure.

\section{Method}

The writer collected some paragraph writing that have taken from the students. In this case, it was analyzed the uses of Cohesive devices in constructing paragraph. The students as the object of the research were given some instructions. They were going to write some paragraphs based on the topic that determined. An error analysis as the concept was required in the case of analyzing the uses and its error of cohesive device 
as well as its dominat that were made up of the students. Even there were two ways that are used. The first is to find out the uses of cohesive device, and the second is to identify the errors and its dominant that made by the students. The objects of these researches was the seventh semester students that have been chosen to constructs some paragraph based on the titles were given.

The subjects of the research were the students of Moslem University of Indonesia. In this research, the writer took the seventh semester students of letter faculty that consists of 93 students as the population. The writer was taken 2011 students to be the sample randomly.

Data that were needed from the papers of the paragraph descriptions of the topics that have been determined. Based on the categories of the data, qualitative data (Cohesion) in the paragraph construction and quantitative data were needed. So, those types of data need statistical approach and non - statistical approach. Qualitative data was got after classifying, identifying and grouping the uses of cohesive device that taken in the sample of writing paragraph.

\section{Result and Disucussion}

the researcher analyzes and expains the types of errors on the use of cohesive devices and the dominant of errors made up of the seventh semester students of English Department of Letters Faculty at Moslem University of Indonesia in writing paragraph.

Types of Error on The Use of Cohesive Devices

After analyzing the students' paragraphs, the researcher finds some errors on the use of cohesive devices. The errors that occur in the students' paragraph writing cover reference, conjunction, and lexical cohesion. Those errors are explained further by the researcher as follows:

\section{a. Reference}

Based on the essays analysis, the researcher finds errors of reference. Those errors occur variously. They occur in the form of demonstrative reference, comparative reference and personal reference.

b. Substitution

There is no error found on the use of substitution. For this reason, the researcher not explains any further for this type of cohesion.

c. Ellipsis

In terms of errors on ellipsis, the researcher also does not find it in the studentse essay. Therefore, she does not explain it any further in this point of finding.

d. Conjunction

From the students es essay, the researcher finds errors on the use of additive conjunction, adversative conjunction and causal conjunction. Error on the use of temporal conjunction is not found.

e. Lexical Cohesion

1. Errors on the use of Reiteration

a) Repetition

Errors on the use of repetition caused by the students repeatedly uses the same word several times that make that make the text becomes dull and monotonous.

b) General Noun

Besides errors on the use of repetition, the researcher also finds Error on the use of general noun.

\section{Errors on the use of Collocation}

The students commit errors on the use of collocation when they have wrong choices of vocabulary.

\section{Determinant of Error}

To explain the dominant of errors on the use of cohesive devices, the researcher makes a table to show the number of errors on the use of each type of cohesive devices.

A total of 25 errors are identified in the 25 studentse ${ }^{\text {ee }}$ paragraph. The table above shows that reference had the highest percentage of errors, $64 \%$, followed by conjunction, $24 \%$ and lexical cohesive errors, $12 \%$. The gap between reference and the other two categories of errors suggests that the former posed the most difficult for the students in writing essays. Substitution and ellipsis errors are not found.

In the sub-categories of reference errors, the highest frequency of errors committed by the students is on the use of demonstrative reference, $28 \%$, followed by personal reference, $28 \%$ and comparative reference $8 \%$. In the sub-categories of conjunction, the highest frequency of errors is both on additive errors, $4 \%$ and adversative errors, $12 \%$. 
This is followed by causal errors, $8 \%$. In the sub categories of lexical cohesion, reiteration has the highest frequency of errors, $8 \%$, followed by collocation errors, $4 \%$.

From the explanation above, the researcher concludes that the first dominant error is reference; the second dominant error is conjunction, and the last dominant error is lexical cohesion.

\section{Conclusion}

This research investigates cohesive devices errors in Paragraph written by the seventh semester students of English department of Letters Faculty at Moslem University of Indonesia. The results of this research are as follows:

1. There are 25 errors on the use of cohesive devices identified in the students ${ }^{\text {ee }}$ paragraph. However, there is no error found on the use of substitution and ellipsis.

2. The types of errors found in the students ${ }^{\text {ee }}$ essay are in the form of reference, conjunction and lexical conjunction. The students commit the most reference errors on the use of demonstrative $28 \%$, personal $28 \%$, and comparative $8 \%$. Those errors occur because the students do not know the function and use of definite article. At the same time, they are not able to use reference cohesion to maintain reference clarity and consistency. In addition, wrong comparatives are used to show comparison. In the subcategories of conjunction, the researcher finds

3. Errors on the use of additive conjunction $4 \%$, adversative conjunction $12 \%$ and causal conjunction $8 \%$. Error on the use of temporal conjunction is not found. Those errors occur because the students use simple additive "and" in inappropriate disposition. They also used adversative for adding to new or more information. Moreover, they confuse between the use of "because of" and "because". Then in the sub-categories of lexical cohesion, reiteration has the highest frequency of errors $8 \%$. This is followed by errors on the use of collocation 4\%. Errors on the use of reiteration especially errors on the repetition of the same words reveal that the students are not able to use reference cohesion, when required. Furthermore, they are unable to use ellipsis, when necessary. Errors on the use of collocation indicate that the students have lack vocabularies which have resulted in their inability to elaborate and extend ideas using synonyms or other cohesive devices.

4. As the percentage of reference errors is $64 \%$, conjunction errors is $24 \%$ and lexical cohesion errors is $12 \%$, the res earcher concludes that the first dominant error is reference, the second dominant error is conjunction and the last dominant error is lexical cohesion.

\section{Reference}

Brown, H. Douglas. (1980). Principles of Language Learning and Teaching. New Jersey, Prentice Hall.

Gerot. L., \& Wignell, P. ( 1994 ). Making Sense of Functional Grammar. Australia: Antipodean Educational Enterprises.

Halliday, M. A. K., \& Hasan, R. (1976). Cohesion in English. London: Longman.

Hogue, Ann. 1996. First Step in Academic Writing. Addison - Wesley Publising Company. Inc, Longman.

McCarthy, M. (1991). Discourse Analysis for Language Teachers. Cambridge: Cambridge University Press.

Oshima, Alice and Hogue, Ann. (1988). Introduction to Academic Writing. United States: Addison-Wesley Publishing Company, Inc.

Oxford. (2008). Lernar's Pocket Dictionary. Oxford Univercity Press.

Richard, Jack, C. (1974). Error Analysis: Perspective on Second Language Acquisition. London.Longman Group ltd.

Sattayantham, A \& Ratanapinyowong, P. 2008. Analysis of Errors in Paragraph writing in English by the first year medical students from the four medical schools at Mahidol University. Silapokan University International Jurnal. 8:17-38.Doi.

Sukandarrumidi. (2004). Metodologi Penelitian : Petunjuk Praktis Untuk Peneliti Pemula. Yogyakarta: Gadjah Mada University Press. 
Wijaya, Cannie. (2001). A Study of cohesion in the essays of students of writing IV, of the Faculty of Letters, Petra Christian University. Surabaya : Petra Christian University.

Zemach, Dorothy E \& Rumisek, Lisa A. 2005. Academic Writing from Paragraph to Essay. London: Macmillan Press 